\title{
National Trauma on a Foreign Stage
}

\section{PIRKKO KOSKI}

\begin{abstract}
This article surveys the performance of the play Departure (Lähtö in Finnish, Minek in Estonian) by Estonian Rein Saluri at the Finnish National Theatre in 1988 during the last few years of the Cold War. The play depicts the deportation of an Estonian family to Siberia in the fall of 1946. The Finnish National Theatre invited Estonian Mati Unt to act as the director. The actors were Finnish, as were the audience, apart from a few individual spectators and during a short visit when Departure was performed in Estonia.

The aim is to analyze how a theatre performance connected with an aspect of Estonian traumatic history and national memory was understood and felt by a country with a different historical and contemporary background. The performances of Departure show the ways in which repetition, memory, and reappearance work and function in the theatre. Departure as theatre had power over history in its ability to reshape the image of the past through physical presence and affection. It increased in Finland the knowledge of and empathy toward Estonia and the presence of Estonian culture before the great political upheavals. However, the Finnish audience constructed the meanings of the play without the interaction between the collective memory, that is, the Finnish "memory" was historical and theatrical. Concerning national collective memory, it was not possible to cross the border.
\end{abstract}

\section{KEYWORDS}

The Finnish National Theatre, Estonian drama, deportations, memory, history. 


\section{National Trauma on a Foreign Stage}

The performance of a new play Departure (Lähtö in Finnish, Minek in Estonian) by Estonian Rein Saluri (b. 1939) at the Finnish National Theatre in 1988 coincided with the last few years of the Cold War. The play depicts the deportation of an Estonian family to Siberia in the fall of 1946 and the two hours the family had time to prepare before leaving their home behind. To ensure the authenticity of the depiction, the Finnish National Theatre invited Estonian Mati Unt (1944-2005) ${ }^{1}$ to act as director. The man responsible for the music was Estonian Erkki-Sven Tüür, who had worked with Unt on numerous occasions. The rest of the artistic team were Finnish, as well as the audience, apart from a few individual spectators and the short visit when Departure was performed in Estonia.

I examine the performance event of Departure as a meeting place where theatrical, social, and national currents and conceptions of history exist side by side and influence each other. I aim to analyze how a theatre performance connected with Estonian traumatic history and national memory was understood and felt by a country with a different historical and contemporary background. Shared national experience, history, and memory are essential in Departure and greatly shaped the theatre event and its reception. The theatrical production of a fictional story and the real-life traumatic allusions Departure presented came together with the experiences the interpreters had of theatre and society.

Trauma means experiencing an overwhelming catastrophic event and working with it leads to a struggle between memory and forgetting. In trauma fiction including theatre performances, we, as spectators, have differing relations to the event. When it comes to the transnational currents like in my survey, we may get into a situation where the inclusion of "another" succeeds

1 Mati Unt was known in Finland mainly as a writer, but Finns could also have been familiar with his work as a dramaturg and director in 1986, when the Pärnu Theatre visited the National Theatre and performed his The Witching Hour in Jannseni Street (Vaimude tund Jannseni tänaval), a play about the fictive meeting of Aino Kallas and Lydia Koidula. Unt himself had had difficulties in travelling abroad because of his former open political statements. His work as a director now in Finland testifies to the rapid change in the political climate in Estonia. See Koski 2019, 238; Kiin, Ruutsoo and Tarand 1990, 7-15. 
inadequately. However, it does not make the performance unimportant.

The performance of Departure was the first Estonian contemporary work shown at the post-war National Theatre, even though its relations with Estonia were becoming more active throughout the 1980s, as was the case with the Finnish theatres in general. In Finland, this personal historical account by an Estonian author, written in the climate surrounding the late 1980s, and the theatrical interpretation of an Estonian director met an audience that interpreted the performance through the lenses of Finnish historical and theatrical conventions, including even the growing awareness of their own difficult situation between East and West. The performance became a part of the public space, which was rapidly shifting due to the wide news coverage on the political unrest the Soviet Union was experiencing. Departure and its reception not only affirmed and reflected the tides of time, but also transformed the social space around them.

\section{Theatre Performance as a Meeting Place}

Multiple studies have addressed the theatrical performance as a reflection on collective and personal identity as well as the image of the past. Dramatic and theatrical space have also been of great interest to many researchers during the last few decades.

Marvin Carlson and Freddie Rokem, among others, have surveyed theatre and performance as a place of repetition and memory. In his The Haunted Stage (2001), Carlson characterizes theatre as a "memory machine" and extends the concept of "re-appear", typical of a performance, to concern different components of theatre, reception included. ${ }^{2}$ In his Performing History (2000), Rokem connects re-membering with the meaning of theatre as the witness and interpreter of history. The theatre productions, which have raised wide public discussion in different countries, have reshaped the image of the past and analyzed collective identities in a new way. ${ }^{3}$ The performance Departure, as a specific place, can be compared with the larger European context. At the same time, deportations as its subject matter tie it especially to the Baltic context, which has been discussed e.g. in We Have Something in Common: The Baltic Memory (2007).

In many cases, theatre plays depicting historical events concern a traumatic past. Milija Gluhovic, for instance, focuses on the relationship between such theatre plays and historical memory and raises serious questions about totalitarian power in his Performing European Memories: Trauma, Ethics, Politics (2013). Jeanette Malkin discusses in Memory-Theater and Postmodern Drama (2010) contemporary plays and memory, and she touches on similar themes like Gluhovic about trauma and ethics.

When national and individual history, as well as memory, are focused, a general historical viewpoint offers support to a performance analysis. Philip Gardner has discussed in Hermeneutics, History and Memory (2010) the relationship between memory and history. According to him, history strives to

2 Carlson 2001, 1-15.

3 Rokem 2000, 6-9. 
unravel the past for the present and create a connection across the temporal separation. Memory on the other hand is directly tied to the past in the form of humane consciousness. ${ }^{4}$ In Departure, memory and history challenge the historian to consider these questions from both a national and individual perspective. As the production in question represents two different cultures, the survey also requires a transnational perspective.

Doreen Massey and the researchers who have addressed the problem and developed her views on space and time, offer a serviceable research frame for different viewpoints. According to Massey, the social relations that evolve with the flow of time interact with the history attached to a specific place. Time represents a temporal dimension, as a spatial dimension is typically manifold. ${ }^{5}$ Mikko Lehtonen (2013) sees the spatial experiences as simultaneous and open processes; as structured actions, where local, national, and transnational actions join in varying ways - as was the case with the performance event of Departure. ${ }^{6}$ When discussing theatre, history, and memory, Luule Epner reminds how theatre as a collective art form is especially suitable for mediating the images of the past. She refers to how, in theatre, "past events pass through several filters, including ideological constraints." Theatre productions are based on "a kind of interpretative model, sometimes implicit in the performance, sometimes explicit." In my case, filters are often also national although the production has been created by and of the factors crossing the border.

All these studies share an idea of theatre and performance as an event, and consequently, as a meeting place of different currents. My aim is to survey and analyze what happened around Departure and what kind of meanings it created among the spectators and the cultural atmosphere of its time. One of the 'filters' is crucial: my survey becomes a Finnish viewpoint to a transnational event, while not having an approach to the sources in the Estonian language or to Estonian collective memory. This shortage becomes an extra task to be exposed.

\section{The Play and its Interpretation on Stage}

The author of Departure, Rein Saluri, personally experienced the deportation of his family as a child. The play is based on the series of events he is familiar with. This kind of knowledge was generally shared in Estonia. The play premiered at the small Willensauna Stage on 7 October 1988, and beside the Estonian director Mati Unt, dramaturg Terttu Savola, stage designer Eero Kankkunen, and costume designer Sara Popovits were Finnish. The cast consisted of several main actors of the National Theatre. ${ }^{8}$

The most impressive thing in Departure is the subject matter, that is, the preparations a family must make after hearing a deportation to Siberia is

4 Gluhovic 2013, 4.

5 Massey 2008, 14.

6 Lehtonen 2013, 11-14, 20.

7 Epner 2007, 122-123.

8 As mother and children of the Kask family, Marita Nordberg, Kaius Niemi, and Misa Palander; Pekka Autiovuori as Rass, Risto Aaltonen as Lembit, Terhi Panula as teacher Luule, and Jukka Puotila as Officer. 
imminent. The scene is a farmyard. The mother and the three children to be deported have been listed, and in the beginning, only the mother is present; however, someone seems to hide in the attic. The father has been deported prior to this, and a dead grandfather, Priidu, is waiting for transportation to arrive in order to be buried. Special Commissioner Rass and an officer with soldiers have arrived, and the incoming Uncle Lembit raises tension on stage. Two of the children will be picked up from school, and their teacher and mourning villagers arrive in order to go with the dead Priidu's coffin to the graveyard. The youngest boy, also Priidu, stays away, and in their hurry the men carrying out the deportation mistake the name referring to the dead and soon-to-be buried grandfather, Priidu. In the end, the family leaves for the unknown, and the small Priidu comes down from the attic and remains alone on stage. An extra thing giving rise to tension is narrated time, the two hours to decide what to take and what to leave behind. The greatest dramaturgical tension rises between the knowledge the readers and the audience members have, and the recognizability of the events depicted.

Character depictions offer no surprises. The close village community is portrayed as good and supportive of its members. Treachery is represented by Special Commissioner Rass from the fringes of the community, yet still from within the village sphere. The evil committed by complete outsiders is caused by the system itself, rather than personality traits.

For director Mati Unt, the subject matter was meaningful, but he also emphasized the value of the play as a theatrical text. According to Unt, the therapeutic effect the play had was important to Estonians. Even though Rein Saluri was writing his autobiography, compared with other contemporary Estonian glasnost plays, his was purer and more straightforward on the surface - more universal. Unt also said that to Finns the play still had to mean something other than what was unique in Estonia. For him, the tragicomedy (like the dead grandfather in his coffin in the middle of the farmyard) of the play offered a slice of absurdity and universal sparsity, tragedy, and black humor. To Unt, the play was thematically about a young man (Rass) betraying his own village and about hopeless subjugation. ${ }^{9}$

The video recordings of the play illustrate the interpretation on stage. The ambiance within the opening scene is sparked by the loudly played International (Kansainvälinen), and the funeral hymn later sang by the women turns into a declarationesque counterbalance against the political message of the beginning. The aggressive physicality the character of Rass has, enhances the contrast between the informant and other villagers and proves to be more prominent than the one expected when reading the play. This highlights the theme of betrayal Mati Unt had mentioned. On the other hand, to Finns, Rass's long leather coat referred to an image of an international communist instead of a deceitful Estonian neighbor. Few slowdowns emerge from the otherwise realistic depiction; as something akin to the internal speech of the characters. Based on the video recordings, it seems these sporadic style switches do not always fit into the overall realism. Even a low-quality recording conveys the

9 Talvitie Ilta-Sanomat 17.9.1988, Piila Kotimaa 2.9.1988. 
emotional power of the content. ${ }^{10}$

The Finnish press wrote a great deal on the play and the performance. ${ }^{11}$ Among the premier reviews, most people unanimously agreed on the impressiveness and importance of the subject matter. Departure was considered a documentary play about a specific historical period; "that purpose the play fulfills."12 According to Kirsikka Moring, Rein Saluri "writes about his own life and experiences, mirrors them in the life of the Kaski family and, more broadly, in the national tragedy that affected tens of thousands of Estonian families." She also considered Saluri a fully-fledged tragedian. The thick tension at the Willensauna Stage was impressive. The play "was at its best a series of robust dynamic situations where different components correspond." ${ }^{13}$ However, many felt the acting was occasionally uneven and stylistically disperse. In Finland, this was not experienced as a conscious stylistic emphasis.

The video recordings show that the director did not strive for an intact realistic style and narrative, which many critics would have deemed more successful than the theatre-like interpretation. To that extent, the director's intention was not open to the Finnish audience. Finns felt sympathy towards the suffering the Estonians faced, but when the actual personal pain caused by the traumatic experience was absent, they saw no need to alienate the events, for example, with the use of grotesque and absurdity.

\section{Crossing the Borders}

When Departure was staged, perestroika was going on in the Soviet Union. Heikki Rausmaa places the beginning of his examination of Estonian and Finnish relations to the Estonian "singing revolution", the same year, 1988, Departure was premiered. ${ }^{14}$ That spring, the criticism Estonians showed towards the Communist Party moved on quickly, the Popular Front of Estonia was introduced, and the Party had a shift in its policy. Revealing the country's history became a popular topic in public conversation. The deportations were openly confirmed as terror, instead of seeing them as a historical erroneous inevitability. Theatre had a pivotal role in the new process of awareness. ${ }^{15}$

In interviews at the beginning of the autumn of 1988, Mati Unt stated that he had never believed in popular movements or great lodestars. According to him, Estonians had always been outspoken, and now it was openly possible. He saw at least economic sovereignty as being possible, provided that the leaders of the country acted cleverly. ${ }^{16}$ His cautious opinions seemingly differ from the interpretation of the play and may tell something about the unpredictable atmosphere of that time. Unt used theatre and not the press as a means of his expression.

The official Finnish politics avoided open support to the Estonian national

10 Video recordings in the National Theatre Archive.

11 The National Theatre Archive, the collection of the reviews.

12 Lehtonen Kansan Uutiset 25.10.1988.

13 Moring Helsingin Sanomat 9.10.1988.

14 Rausmaa 2013.

15 Zetterberg 2007, 703, 720-722.

16 Blomstedt Helsingin Sanomat 18.9.1988, Talvitie Ilta-Sanomat 17.9.1988. 
movement, but behind this surface, culture became an important and a state financed channel for cooperation. "In the name of culture, you can go on for a lot", was president Mauno Koivisto's private advice to the Minister of Culture. ${ }^{17}$ In Finland, the number of friendship societies grew drastically, and communication increased also in many other fields. The media articles aided in increasing sympathy towards Estonia, and in part also reflected the interest the citizens had. The international mobility between the Finnish National Theatre and Estonian theatres was brisk and expanded even further during those years. ${ }^{18}$

In both countries, the thinking had been defined by geographical and political positions. While researching the recent history of Eastern Europe, Katalin Miklóssy has described the countries (including Estonia) that gained their independence after the Great War and later were under the influence of the Soviet Union with a phrase "in between", a situation of being between the East and the West. According to her, this navigation also stimulated culture and general advancement. ${ }^{19}$ The same phrase as such cannot be applied to Finland, which was in the West and had a different political system, but Finland for its part navigated between the West and the countries "in between".

In The Tracks of Colonialism, Mikko Lehtonen and Olli Löytty situated Finland both to the center of the West and to the periphery of that center. In a country with a sparse population, the import of culture exceeded its export, and the national high culture was cosmopolitan with a "foreign" western identity. ${ }^{20}$ That was also a base for national imagery. Perhaps it was due to the political position of Finland that the Estonian deportations had not been common topics in the official cautious conversation during the decades of the Cold War, even though the events were acknowledged and there were no obstacles to discussing them.

Although Departure was the first Estonian contemporary play staged at the National Theatre during these decades, it represented the theatre's general interest in the countries behind the iron curtain. Theatre director Kai Savola had created active contacts with these countries, but he had not followed the cautious official politics of the country. His predisposition towards the Eastern European mavericks and dissidents had been apparent during his whole tenure as theatre director. Savola had also already long been searching for a new sophisticated Estonian drama. ${ }^{21}$

The universality of the play Mati Unt saw was not experienced by the Finnish audience. They were, however, sympathetic toward the performance of Departure. The history of the two countries also remained separate. The Finnish reviewers showed support towards the liberated atmosphere in Estonia and thanked the Finnish National Theatre for making the wrongs of the past known, but the message the play had was seen through sympathetic outside eyes. The play was linked to Finland only through circumstance; for example, when Eila Jokela pondered, in her New Finland (Uusi Suomi) column, would

17 Rausmaa 2013, 2. [Subtitle of his book.]

18 Rausmaa 2013, 31-33.

19 Miklóssy 2018, 32.

20 Lehtonen and Löytty 2007, 110-112.

21 Koski 2019, 237-238, 311-312. 
the same fate have awaited Finland if the country had not been defended during the Second World War. ${ }^{22}$ Not even an adjacent production on the main stage of the National Theatre about the danger of war in 1939 created wider connections to Finland. During the spring of 1989, the play Road to the Winter War (Tie Talvisotaan) by Heikki Ylikangas depicted the negotiations carried out between Finland and the Soviet Union during fall 1939. Ylikangas believed that the cession of territories could have prevented the Winter War from ever happening. Surprisingly, during its reception, no attention was given to Departure, which was performed simultaneously on the Willensauna Stage, even though the programme of Ylikankangas' play claimed the cession of the Estonian territories in 1939 later lead to the military occupation. ${ }^{23}$

\section{National History and Memory}

According to Philip Gardner, memory is defined by both collective and personal identity: singular memories reveal the collective structures of meaning, and recollections are transforming when repeated. ${ }^{24}$ When examining oral history, Jorma Kalela refers to the idea of "from lived relations to real societal relations". He thinks it is important to solve why a human being remembers and recites his memories in a certain way. ${ }^{25}$ Milija Gluhovic's aspect of the oral history of performance with regard to psychological trauma and mourning is especially interesting when examining Departure. Facing the past also leads to ethical contemplation. ${ }^{26}$

In the performance of Departure, the depiction of the past was layered: the author had created a story built partly from personal experience and based on a historical event, which the theatre ensemble interpreted through their own choices under the theatrical conventions. As a historical event, the subject matter had been admissible in Finland and long forbidden in Estonia, yet it was understandable in both countries and the depiction helped both countries to better comprehend the past. Alternatively, as a proof of individual and collective memory, the play was seen in a very different light depending on the history and memory related experiences the performers and the audience had, and these differences were also national.

An integral part of the theatre is that the spectator feels the performance as personally meaningful. Director Mati Unt believed that some Finns would parallel the story with the forced migration from the relinquished Karelia and associate it with personal memories. Yet, the concrete nature of history works against this or at least works differently, although the past of some of the actors as war-time Karelian migrants may have influenced their working processes. Finns had escaped during the war to another part of their homeland attacked by a foreign country. They might have understood the feeling of leaving one's home behind, but as a collective experience, the departure from Karelia meant

22 Jokela Uusi Suomi 9.12.1988.

23 Koski 2019, 237-238, 311-312.

24 Gardner 2010, 203: Repetition changes memory, because the presence is also timely.

25 Kalela 2006, 77-79, 87.

26 Gluhovic 2013, 4. 
escape to safety, not the other way around.

The relationship Finns had with the deportation of an Estonian family was historically based, and the performance strengthened this knowledge. The artistic team of the Finnish National Theatre became very familiarized with Estonian history, as, in addition to the director, e.g. Rein Saluri and his wife Piret had visited to expand on the background of the play, and many other notable cultural figures of Estonia were there to guide them into the Estonian realities. The performers aimed at giving a historically valid frame to the story. Pre-reviews stated the author himself had been deported, and the programme included facts about Estonian history. The performers gained an extra documentary connection to the story in the premier. Among the audience, Karl Õiger, who, like Saluri, had once been secretly sent back from Siberia to school in Estonia, turned out to be the real-life inspiration behind the schoolboy in the play. ${ }^{27}$

Even though the deportations were not a part of the collective memory of the Finnish audience, the spectators might have experienced the feeling of capturing something more than just a fictitious world or new historical knowledge. By identifying with the documentary-like characters, the audience might have been able to create an experience to the past that was stronger than history. ${ }^{28}$ Theatre can bring the audience experience closer together in a direction that is "lived" through staging the historical narrative. During the performance of Departure, the physical presence and the feeling of authenticity characteristic of theatre built an affective space and supported the spectator's identification with the world based on real life.

However, "to experience as if lived" was born during the performance's present time and despite the emotional nature, there was no straight link to the individual or collective memory. It was still fiction. Estonian Lea Tormis was clearly on the right track when she wrote that Finns living in welfare are not fully able to comprehend the emotions the Estonian play gave birth to. To Estonians, the deportations represented a national trauma that had been buried deep for decades. ${ }^{29}$ Remembering demanded participation.

\section{Facing Another's Memory and Trauma}

For Estonians, remembering the past also included the knowledge of treachery by one's own people, the division and guilt the people had - all aspects the director emphasized. While examining European theatre performances depicting traumatic events, Milija Gluhovic has pondered on the ways theatre can help different communities to manage their past. For example, in the plays directed by Tadeusz Kantor, identifying the past was able to lessen the bitter wounds and traumas based on false identifications. When reiterated ethically

27 Niemi Teema 4/2015.

28 Seppo Knuuttila writes how a place experienced as lived, experienced and narrated will create a dialogue between a larger social and cultural formation, instead of being subjugated. Knuuttila 2006, $9,7$.

29 Tormis Teatteriväki 2/1989. 
and responsibly, stories have a positive and vitalizing effect. ${ }^{30}$ Jeanette Malkin also alludes to the importance of sincerely facing a distressing experience and to the importance of drama in building a vitalizing dialogue. Even more traumatic than a distressing experience is the inability to face the experience, which subsequently will impede its processing. ${ }^{31}$

To Estonians, the deportations were traumatic in many ways: as the remembrance of innocent victims and the knowledge that some Estonians participated in the injustices, and because this topic had been strongly censored for decades. The Estonian director wanted to perform the memory of betrayal, but by using absurd methods avoid sentimentality and melodrama. In Finland, the pain which the victims felt was met with sympathy, or more, with empathy. Conversely, Finns did not emphasize the betrayal by one's own people in the story. Their "guilt" meant no more than their local procedure of keeping their distance from the Estonian political situation in order to ensure safety in their own country, that is to say, avoiding supporting the Estonian uprising. They may also have re-membered that this tragedy could have happened even to themselves. To overcome these feelings, only empathy and criticism towards the current official politics were needed. It was not a trauma. All this testifies to the fact that crossing a national boundary entirely is not possible. Transnationalism has limitations.

When the National Theatre visited with Departure in Tallinn in the spring of 1989 , its performance was not a premier for Estonians. The play had already been performed at two Estonian theatres and at one in Lithuania. However, during the visit to Estonia, the theatre event was seen from an alienated viewpoint, through another country's performance or audience - from the other side of the Iron Curtain. Estonian Lea Tormis reminded the readers of the importance of creating bridges and made a reference to the old history between two countries, to Aino Kallas, a Finnish-born writer living in Estonia before the war. To Tormis, the most suggestive thing and the secret of theatre was the living connection between people. ${ }^{32}$ This situation touched both performers and the audience.

The national meaning of the deportations was seen in a new light by the Finns during the performance's visit to Estonia. When the audience changed into Estonians - to those that collectively remembered the events - the actors experienced the encounter closer. "There were many who turned down their voices while reciting their experiences", writes Kaius Niemi who had played the schoolboy. "Estonia was still a part of the all-Union superpower, and human life meant little when its gears were turning. Such a collective experience of structural violence was alien to us Finns who were born after the war. Therefore, we returned to Helsinki humbled and thoughtful." 33 Lea Tormis thought that in Tallinn, compared with the performance she had seen in Helsinki, the actors had a more personal and aching relationship with the events. According to her,

30 Gluhovic 2013, 249-250.

31 Malkin 1999, 13, 31.

32 Tormis Teatteriväki 2/1989.

33 Niemi Teema 4/2015. 
this might have been due to the ever-increasing engagement and reactions the slightly reserved Estonian audience had shown, the larger size and seediness of the Estonian theater's home stage, or the surrounding Estonian life overall. ${ }^{34}$

In 1988, the time of prohibitions was near to Estonians and the feeling of danger still apparent. The performers met an audience with strong ghosts in their pasts, which influenced them as well as their performance. It reminds us that theatre is a living event with participating people and dependent on surrounding differing currents.

\section{In Conclusion}

The performance of Departure at the Finnish National Theatre became a forum for different national characteristics. In that meeting place, two national histories and manifold contemporary currents influenced the way in which the production was experienced.

Finns recognized the tragic events the Eastern European border states had experienced yet had themselves been spared from. The Finnish audience constructed the meanings of the play without the interaction between collective memory and history, that is, the Finnish "memory" was historical and theatrical. Concerning national collective memory, it was not possible to cross the border.

The performance of Departure at the Finnish National Theatre increased the knowledge of and empathy toward Estonia, and the presence of Estonian culture before the great political upheavals. In this way, the production was involved in the motions that would, after a few years, alter decisively both the boundary between the two countries and the whole of Europe. The performance was a success, but in Finland it remained the only interpretation of Saluri's work and was produced only at the end of the 1980s. The Finnish National Theater had no trouble criticizing the communist society, but the lack of other productions during that time may tell that its policy was not a common one in Finnish theatres.

During the performance event, the public discourse on the Estonian situation was intensive, and quite possibly shifted the play towards a politically significant fiction with a real-life background, rather than a universal drama. According to the National Theatre's programme, Rein Saluri himself stated that societal events left little time for aesthetics - the content was what mattered in 1988. The Finnish recipients inevitably enriched their theatre experience with both the historical meaning and the timely importance of unraveling the past. These aspects emphasized history and content over formal theatrical values. It raised empathy through theatrical presence, but the principles around the aesthetic form remained unclear without the sense of experienced danger and trauma.

The brief success of Saluri's play raises other questions as well. Milija Gluhovic, while surveying theatre performances associated with a panEuropean collective memory, has drawn attention to the fact that the systematic political persecution in the Soviet Union has not received cross-border attention. "Moreover, the suffering experienced by the many millions of victims of the Soviet regime, deported to Gulags, tortured, exploited as forced laborers and

34 Tormis Teatteriväki 2/1989. 
murdered, has not yet become an integral part of a pan-European memory landscape." ${ }^{35}$ From this viewpoint, Departure ought to have raised special and larger interest as being a quite rare representative of these wrongs, but its success remained local and did not lead to new productions. It seems to have been bound to time and space and to a documentary image. Its content and the way in which the dramatic tension based on the spectators' knowledge of the past overshadowed aaesthetics and interest as a piece of art. This content lost its interest after a few years when the Iron Curtain began to fall apart, and the general discussion moved on to a larger, more public sphere.

The performances of Departure show the ways in which repetition, memory, and re-appearance work and function in the theatre. Their influence and meaning depend on the differing currents which become actualized for the attending people. The power of theatre is situated in its quality as a meeting place, including human presence. All currents do not cross borders, but performance can create a special connection. Finns did not manage to capture the feeling of collective memory, but Departure as theatre had power over history in its ability to reshape the image of the past through physical presence and affection.

Trans. Nicolas Harju

\begin{abstract}
AUTHOR
Pirkko Koski is Helsinki University's professor emerita of theatre research. She has specialized in performance analysis and historiography, as well as historical analysis of the Finnish theatre. She has written and edited several articles and books for the domestic and international market. Her most recent works include 2019's monograph Suomen Kansallisteatteri ristipaineissa (The National Theatre of Finland meeting pressure conflicts), and 2013's monograph Näyttelijänä Suomessa (Being an actor in Finland).
\end{abstract}

\title{
REFERENCES
}

Carlson, Marvin. 2001. The Haunted Stage. The Theatre as a Memory Machine. Ann Arbor: The University of Michigan Press.

Epner, Luule. 2007. "Rupture and Continuity: How History and Memory Are Represented on the Stage." In Anneli Mihkelev and Benedikts Kalnačs (eds). We Have Something in Common: The Baltic Memory. Tallinn: The Under and Tuglas Literature Centre of the Estonian Academy of Sciences and Institute of Literature, Folklore and Art of the University of Latvia, 177-196.

35 Gluhovic 2013, 7. 
Gardner, Philip. 2010. Hermeneutics, History and Memory. London and New York: Routledge.

Gluhovic, Milija. 2013. Performing European Memories: Trauma, Ethics, Politics. Basinbroke and New York: Palgrave Macmillan.

Kalela, Jorma. 2006. "Muistitiedon näkökulma historiaan." In Outi Fingerroos, Riina Haanpää, Anne Heimo, Ulla-Maija Peltonen (eds.). Muistitietotutkimus. Metodologisia kysymyksiä. Helsinki: Suomalaisen Kirjallisuuden Seura, 67-92.

Kiin, Sirje, Rein Ruutsoo, and Andres Tarand. 1990. Neljänkymmenen kirje. Kokemuksia neuvostotodellisuudesta. Translated by Jaakko Anhava, Tapio Mäkeläinen, Juhan Kristjan Talve. Helsinki: Otava.

Knuuttila, Seppo. 2006. "Paikan moneus." In Seppo Knuuttila, Pekka Laaksonen, Ulla Piela (eds.). Paikka. Eletty, kuviteltu, kerrottu. Helsinki: Suomalaisen Kirjallisuuden Seura, 7-11.

Koski, Pirkko. 2019. Suomen Kansallisteatteri ristipaineissa - Kai Savolan pääjohtajakausi 1974-1991. Helsinki: Suomalaisen Kirjallisuuden Seura.

Lehtonen, Mikko. 2013. "Miten tutkia liikkuvaa maailmaa." In Mikko Lehtonen (ed.). Liikkuva maailma. Liike, raja, tieto. Tampere: Vastapaino, 7-29.

Lehtonen, Mikko, and Olli Löytty. 2007. "Suomiko toista maata?" In Joel Kuortti, Mikko Lehtonen, Olli Löytty (eds.). Kolonialismin jäljet: keskustat, periferiat ja Suomi. Helsinki: Gaudeamus, 105-118.

Malkin, Jeanette R. 1999. Memory-Theater and Postmodern Drama. Ann Arbor: University of Michigan Press.

Massey, Doreen. 2008. Samanaikainen tila. Translated by Janne Rovio. Tampere: Vastapaino.

Miklóssy, Katalin. 2018. "Alueellisuuden merkitys: kehityksen ongelmat ja voimavarat." In Katalin Miklóssy, Jouko Nikula (eds.). Demokratian karikot. Itäinen Eurooppa suuntaa etsimässä. Helsinki: Gaudeamus, 30-51.

Rausmaa, Heikki. 2013. "Kyllä kulttuurin nimissä voi harrastella aika paljon." Suomen ja Viron poliittiset suhteet keväästä 1988 diplomaattisuhteiden solmimiseen 1991. PhD thesis, University of Helsinki.

Rokem, Freddie. 2000. Performing History. Theatrical Presentations of the Past in Contemporary Theatre. lowa City: University of lowa Press.

Zetterberg, Seppo. 2007. Viron historia. Helsinki: Suomalaisen Kirjallisuuden Seura.

We Have Something in Common: the Baltic Memory. Anneli Mihkelev, Benedikts Kalnačs (eds.). Tallinn: The Under and Tuglas Literature Centre of the Estonian Academy of Sciences and Institute of Literature, Folklore and Art of the University of Latvia, 2007. 


\section{Newspapers and magazines}

Blomstedt, Jan. 1988. "'Pidän kissoista, en ihmisistä.' Mati Unt ei usko suuriin sanoihin." Helsingin Sanomat 18.9.1988.

Jokela, Eila. 1988. "Uutta ja raikasta." Uusi Suomi 9.12.1988.

Lehtonen, Soila. 1988. "Virolaista dokumenttiteatteria Kansallisteatterissa. Lähtö Siperiaan." Kansan Uutiset 25.10.1988.

Moring, Kirsikka. 1988. "Lähtö. Koskettava näytelmä virolaisten pakkosiirroista." Helsingin Sanomat 9.10.1988.

Niemi, Kaius. 2015. "Sain kukkakimpun ja paljon muuta." Teema 4/2015, 78-81.

Piila, Liisa Maria. 1988. "Virolaista glasnostia valmistuu Kansalliseen: kaksi tuntia ennen Siperiaa." Kotimaa 2.9.1988.

Talvitie, Liisa. 1988. "Viro ei enää vaikene. Mati Unt ohjaa näytelmän pakkosiirroista Siperiaan." Ilta-Sanomat 17.9.1988.

Tormis, Lea. 1989. "Lahdentakainen silmäys virolaiseen historiaan." Teatteriväki 2/1989.

\section{Archives}

Lähtö. [Prompter's book.] The National Theatre Archive of Finland. Lähtö prompter's book and videorecordings.

Lähtö. [Videorecodings.] The National Theatre Archive of Finland. Lähtö prompter's book and videorecordings. 